Nig. J. Biotech. Vol. 37(1): 109-121 (June 2020)

ISSN: 01891731

Available online at

http://www.ajol.info/index.php/njb/index

and www.biotechsocietynigeria.org

DOI: https://dx.doi.org/10.4314/njb.v37i1.12

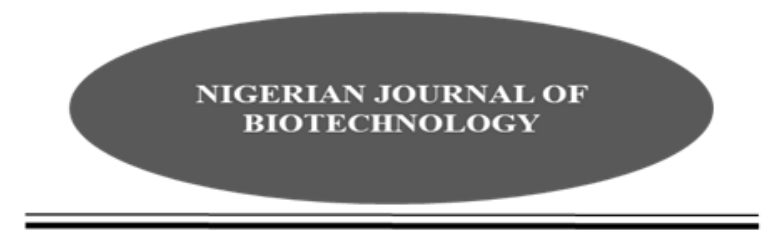

\title{
Indole -3- Butyric Acid Induces Plant Regeneration From Stem Cuttings Of Three Medicinal Plants
}

\author{
Okafor, C.U., Njoku E. U., Ike F. C. and Onyekwuluje, C.C \\ Department of Plant Science and Biotechnology, University of Nigeria, Nsukka
}

\begin{abstract}
Field regeneration of three (3) medicinal plants - Securidaca longepedunculata (violet tree), Ocimum gratissimum (scent leaf) and Pterocarpus mildebraedii by means of rooting of stem cuttings at different lengths of $10-15 \mathrm{~cm}$ and $15-20 \mathrm{~cm}$ were studied. The effect of the plant hormone Indole-3-Butyric acid (IBA) at $5 \mathrm{~g} / \mathrm{I}$ was tested on rooting, bud sprout and leaf formation of the rooted stem cuttings of the plant species as well as the effect of the length of the stem cuttings on their growth and survival rates. The results of the study revealed that stem cuttings of 0 . gratissimum treated with IBA and the control treatment sprouted within 5 - 8 days. The treated $O$. gratissimum stem cuttings produced a slightly higher number of buds $(2.58 \pm 0.86)$ when compared to the control $(2.00 \pm 0.89)$ with no significant difference at $P \leq 0.05$. Stem cuttings of the treated $P$. mildbraedii cuttings sprouted within $8-10$ days with $1.40 \pm 0.37$ number of buds, with the control showing no sprouts. Consequently, IBA application produced more leaves $(13.00 \pm 5.58)$ and roots $(1.33 \pm 0.01)$ than the control. However, 0 . gratissimum stem cuttings had the highest leaf (13.08 \pm 4.47) and root numbers $(135.00 \pm 13.45)$ followed by the control with values- $13.00 \pm 5.58$ for leaf development and $61.66 \pm 2.34$ for root number respectively. Irrespective of the treatments, none of the stem cuttings of $S$. longepedunculata sprouted. This study showed that exogenous application of IBA to stem cuttings of the tested plants, except $S$. Longepedunculata, improved the root number, number of leaves and number of buds.
\end{abstract}

Keywords: Stem cuttings, Indole-3-Butyric acid (IBA), Rooting

Corresponding author: ebere.njoku@unn.edu.ng

\section{Introduction}

From time immemorial, plants have been an important source of food, fibre and medicine (Nweze et al., 2004; Thangavel et al., 2014). According to the World Health Organization (WHO), about $50 \%$ of people still rely primarily on traditional remedies such as herbs for their medicine and $65 \%$ of Indian populace domicile in rural areas use traditional form of medicine to meet their primary health needs (Alice et al., 2014). Of the medicinal plant species, about $10 \%$ are cultivated while the larger proportion (90\%) are obtained from the wild. The domestic cultivation of medicinal plants is a well-accepted way of producing plant materials both for conservation and other relevant purposes (Tandon et al., 2009). However, harvesting from the wild poses serious challenges as was seen in cases of many plant species that became 
threatened and this led to the loss of genetic diversity and habitat destruction, disrupting biodiversity which is the store house of species richness (Afolayan and Adebola, 2004; Kuldeep et al., 2012). A lot of resources have been channelled into curbing the loss of biodiversity and various protocols have been successfully established. Unfortunately, not much improvement has been noticed (Tripathi, 2008). Increased use of forest land for other purposes, over exploitation and unscientific collection of flora of medicinal and aromatic plants have enormously depleted the existence and massive demand of medicinal plants (Alice et al., 2014). Due to improved agronomic and medicinal traits, it has been reported that the development of regeneration methods is of major importance in medicinal plant biotechnology. Plant genetic resources are the major biological basis of world food security which, to a great extent, support every life on the planet earth. Hence, conservation of such a buffer is considered fundamental and provides priority in all sectors of global development (Tandon et al., 2009). Plants are totipotent in nature, hence plant biotechnology takes advantage of this property of plant development to solve the issue of decreasing plant biodiversity (Slater et al., 2003). When living organisms are injured or lose parts of their bodies, many are able to regenerate new tissues or organs to minimize the impact of the local damage (Ikeuchi et al., 2016), but the mode of this regeneration varies markedly among taxa (Birnbaum and Sánchez-Alvarado, 2008). The influence of plant growth regulators on plant regeneration has been reported in several medicinal plants by different researchers (Faridah et al., 2011, Sanoussi et al., 2012, Onyeulo et al., 2018). Regeneration is a widely conserved physiological response in both animals and plants (Pulianmackal et al., 2014) and has long been utilized for clonal propagation in the form of cutting and grafting (Melnyk and Meyerowitz, 2015). The regenerative capacity of plant cells can be enhanced when explants are soaked in solutions of plant hormones (Chupeau et al., 2013) with explants from juvenile plants regenerating shoots more effectively than those from the mature plants (Zhang et al., 2015). Indole-3-Butyric Acid (IBA), a plant hormone in the "auxin" group is naturally abundant in potato tuber peels (Ludwig, 2000). It is applied exogenously and has been used successfully as a plant growth regulator promoting rooting (Hunt et al., 2011) and exerting different effects on plant growth and development, e.g. regulating responses of plants against biotic and abiotic stresses (Tognetti et al., 2010). Treating cuttings with auxins increases the percentage of rooting, root initiation, number of roots and uniformity of rooting (Elhaak et al., 2015).

Securidaca longipedunculata (Violet tree) of the family Polygalaceae is a medicinal herb indigenous to Africa (Alafe et al., 2014) occurring in a broad range of vegetation ; it is resistant to bush fires but frost sensitive (Donald et al., 2011). S. longepeduncudata have been employed traditionally for the treatment of various diseases like paralysis (Dawit et al., 2003; Soumen et al., 2012), inflammation (with analgesic properties) (Alafe et al., 2014), infectious diseases (Ojewole et al.,2000), among others. On the other hand, Ocimum gratissimum (African basil) is a perennial herbaceous, drought- tolerant plant (Aguiyi et al., 2000; Elizabeth et al., 2012). In Nigeria, it is found in the Savannah and coastal areas and it is called with various local names such as 'Efinrin' in Yoruba, 'Diadoyal' in Hausa and 'Nchuanwu' in Igbo (Owulade, 2004). It has been used in the treatment of various ailments including diabetes mellitus (Aguiyi et al., 2000), rheumatism, paralysis, epilepsy, high fever, sunstroke, influenza, gonorrhoea and mental illnesses (Soumen et al., 2012). It has antihyperglycemic effects (Simon and James, 2007), so it is transformed to herbal tea and used as anti-diabetic therapy (Mohammed et al., 2007). Pterocarpus mildbraedii of the family Fabaceae is a green leafy vegetable locally known as "Oha ojii" in eastern Nigeria (Rosemary et al, 2015). According to Alice et al., (2014) and Ngwuli et al., (2019), it is indigenous to Africa. Its leaves are used for food and medicinal purposes. It is endowed with antioxidant, hypocholesterolemic, chemo-protective and anti-bacterial properties (Rosemary et al, 2015).

Reports on the methods of regenerating $S$. longepedunculata Fresen using the stem cuttings are lacking. $\quad P$. mildbraedii Harms and $O$. gratissimum $L$ whose leaves serve as a source of food and medicine have been reported to be difficult to root using loamy soil, hence the need for the current study. This study therefore 
is necessary so as to provide an efficient and quick means of regenerating these plant species so as to curb the problem of extinction. Rooting of stem cuttings has proven to be the fastest method of producing large quantities of uniform seedlings, contributing significantly to the conservation of species, future biotechnological exploitation of its medicinal properties and food security, as well as making the species available for future research activities.

\section{Materials and Method}

\section{Plant collection and Soil composition}

Three medicinal plants $-S$. longepedunculata, $P$. mildbraedii and 0 . gratissimum were used in this study. The branches of $S$. long epedunculata and $P$. mildbraedii were obtained from Nkalagu in Enugu State, Nigeria while that of $O$. gratissimum was obtained from the Botanical Garden of Plant Science and Biotechnology, University of Nigeria. The rooting medium was composed of Loamy soil (LS), Sawdust (SD) and Poultry manure (PM) in the ratio of $2: 1: 1$, respectively, all placed in polythene bags and measured to the weight of 12 $\mathrm{kg}$ each. Indole-3-Butyric Acid (5g/l) (SigmaAldrich) was prepared according to the manufacturer's instruction.

\section{Sample preparation}

The branches of $S$. longepedunculata, $P$. mildbraedii and $O$. gratissimum were defoliated and cut at varying lengths of $10-15 \mathrm{~cm}$ and $15-$ $20 \mathrm{~cm}$ long, each bearing nodes. A total number of 52 stem-cuttings were used in this study consisting of 32 treated stem cuttings (10 cuttings of $P$. mildbraedii, 12 cuttings of 0 . gratissimum and 10 cuttings of $S$. longepedunculata) and 20 stem cuttings (5 cuttings of $P$. mildbraedii, 5 cuttings of $O$. gratissimum and 10 cuttings of $S$. longepedunculata.) served as control.

\section{Sample Pre-treatment and Plant Procedure}

The stem cuttings were treated with the rooting hormone IBA $(5 \mathrm{~g} / \mathrm{l})$ and soaked for 24 hrs before planting in an erect position in the rooting medium according to the methods of Sanoussi et al., (2012). The experiment was carried out in a randomized complete block design (RCBD) and set up under a natural partial shade. This was mechanically irrigated daily and the resulting weeds handpicked while observations were made for signs of metabolic activities on the cuttings. The study was carried out during the rainy season (July to September, 2019) under a natural partial shade in the Botanical garden of the Department of Plant Science and Biotechnology, University of Nigeria, Nsukka.

\section{Observations and data collection}

The parameters observed include Period of bud sprouting, number of sprouted buds per stem cutting, period of bud development into photosynthesising leaves, the number of leaves produced which were counted three weeks after planting at intervals of 7 days, leaf lengths and leaf diameters, root formation and effect of stem cutting length on seedling growth and survival. The resulting data were collected and documented.

\section{Statistical analysis}

Data collected were analyzed using one way Analysis of variance (ANOVA) at 95 percent probability levels $(P \leq 0.05)$.

\section{Results and Discussion}

The results of the determination of periods of initial and final bud break varied among the stem cuttings of the 3 medicinal plants studied. The stem cuttings of 0 . gratissimum (both treatments and control) had the earliest period of bud sprout (5-8 days after planting) as seen in fig. 1 and plate 1 . This was followed by the treated stem cuttings of $P$. mildbraedii (8-10days after planting) as seen in fig. 1 and plate 2 with the control showing zero sprout. However, both the treated and the control stem cuttings of $S$. longepedunculata showed zero sprout throughout the study period. 


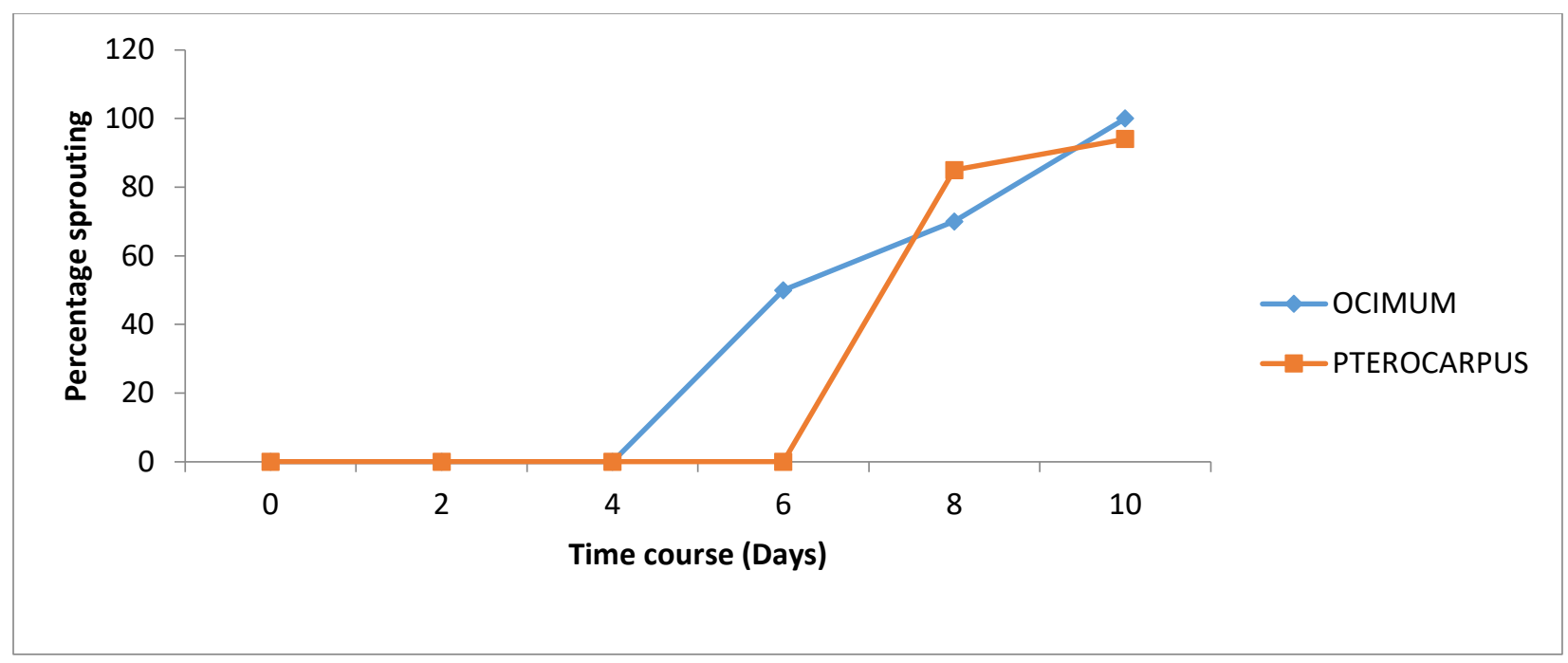

Fig 1: Time course on the percentage sprouting of $O$. gratissimum and $P$. mildbraedii stem cuttings.

From fig.1 above, the time course of sprouting in 0 . gratissimum had $50 \%$ bud sprouts on the $6^{\text {th }}$ day which increased to $70 \%$ bud sprout on the $8^{\text {th }}$ day. On the other hand, P. Mildbraedii had $85 \%$ bud sprout on the $8^{\text {th }}$ day and $94 \%$ bud sprout on the $10^{\text {th }}$ day.

Bud sprouts on all stem cuttings of 0 . gratissimum, including the control, can be attributed to inherent factors in the species. The results of this study on 0 . gratissimum did not conform to earlier reports of Kouakou et al., 2016; Mahipal and Manokari, 2016; and Fadli et al., 2017 who reported that the application of Indole-3-Butyric acid to the stem cuttings of Garcinia kola, Couroupita guianensis and Citrus melo they studied respectively produced significant differences in the mean number of buds compared to their controls. Nevertheless, in the present study, there is no significant difference in the bud mean number of treated O. gratissimum stem cuttings compared to the control. This implies that Ocimum gratissimum can be ranked as an easy to root cultivar.

In terms of the number of buds produced, the treated stem cuttings of 0 . gratissimum produced the highest number of buds (Plate 4) . In contra st to 0 . gratissimum, a higher number of buds was produced in the untreated stem cuttings of $P$. mildbraedii than the treated ones (Plate 3). The inability of the untreated $P$. mildbraedii stem cuttings to produce buds is related to the effect of insufficient hormone inherent in the cuttings.
This is in agreement to an earlier report of Alagesaboopathi (2012) on Andrographis macrobotrys. Alagesaboopathi (2012) stated that the ability of the treated cuttings of $A$. macrobotrys to produce higher numbers of bud sprouts could be as a result of the combined effects of the applied rooting substances and inherent hormones in the plant. On the other hand, S. longepedunculata showed zero sprout. Table 1 shows the number of buds produced by the stem cuttings during the study period presented in their mean \pm standard error values. These variations ranged from $0.00 \pm 0.00$ to $2.58 \pm 0.86$.

In table I, there was a significant difference between the treated (T1) and untreated (control-T2) stem-cuttings of $P$. mildbraedii after 28 and 49 days, respectively . However , there was no significant difference when we compared the treated groups at 28 days and 49 days. The same applies to the untreated groups with no sprouted buds. For 0 . gratissimum, there was no significant difference between the treated (T1) and untreated (control-T2) cuttings. Also, the time difference for T1 did not differ at all. The same holds true for T2 where either sprouts at 28th or 49th day did not differ significantly. $S$. Longepedunculata did not produce sprouts throughout the whole experimental period (49 days) whether treated or untreated. 
Okafor ./ Nig. J. Biotech. Vol. 37 Num. 1: 109-121 (June 2020)

Table 1: Mean number of sprouted buds from stem cuttings of $O$. gratissimum, $P$. mildbraedii and $S$. longepedunculata

\section{$\begin{array}{lll}\text { O. gratissimum } & \text { P. mildbraedii } & \text { S. longepedunculata }\end{array}$}

After 28 days

$\begin{array}{llll}\text { T1 } & 2.50 \pm 0.48 & 1.30 \pm 0.26^{\mathrm{a}} & 0.00 \pm 0.00 \\ \text { T2 } & 2.00 \pm 0.31 & 0.00 \pm 0.00^{\mathrm{b}} & 0.00 \pm 0.00\end{array}$

\section{O. gratissimum $\quad$ P. mildbraedii $\quad$ S. longepedunculata}

\begin{tabular}{llll}
\hline After 49 days & & \\
T1 & $2.58 \pm 0.86$ & $1.40 \pm 0.37^{\mathrm{a}}$ & $0.00 \pm 0.00$ \\
T2 & $2.00 \pm 0.89$ & $0.00 \pm 0.00^{\mathrm{b}}$ & $0.00 \pm 0.00$
\end{tabular}

T1 = Treated with $5 \mathrm{~g} / \mathrm{l}$ of IBA, T2 = Control.

As in the case of the period of bud sprout and number of buds produced, table 2 reveals that treated stem cuttings of 0 . gratissimum showed higher leaf development possessing relatively higher number of leaves, longer leaf length, leaf diameter and higher leaf area than the control with no significant difference in the parameters. $P$. mildbraedii stem cuttings produced less number of leaves than $O$. gratissimum. The stem cuttings of $P$. mildbraedii (control) and that of $S$. longepedunculata produced no leaves. However, not all buds that sprouted in the stem cuttings of $O$. gratissimum and $P$. mildbraedii developed

into leaves. The inability of these sprouted buds to develop into leaves is in agreement with the works of Nzekwe (2002) and Sani et al., (2016). They revealed that not all buds that sprouted on the stem cuttings of Irvingia wombolu and Moringa oleifera persisted till leaf development. Again, there is a significant difference between the treated and the control stem cuttings of $P$. mildbraedii. These variations ranged from $5.00 \pm$ 1.58 to $9.75 \pm 2.02$ for observations made after 28 days of planting and $9.40 \pm 3.05$ to $13.08 \pm$ 4.47 for observations made after 49 days of planting.

Table 2: Number of leaves developed by stem cuttings during the course of the study

\section{After 28 Days}

\begin{tabular}{|c|c|c|c|c|c|}
\hline & & NL & LL (cm) & LD (cm) & LA $\left(\mathrm{cm}^{2}\right)$ \\
\hline \multirow[t]{2}{*}{ Ocimum } & $\mathrm{T} 1$ & $9.75 \pm 2.02$ & $2.53 \pm 0.47$ & $1.33 \pm 0.26$ & $3.53 \pm 0.94$ \\
\hline & $\mathrm{T} 2$ & $6.60 \pm 1.72$ & $1.94 \pm 0.48$ & $1.26 \pm 0.33$ & $2.24 \pm 0.95$ \\
\hline \multirow[t]{2}{*}{ Pterocarpus } & $\mathrm{T} 1$ & $5.00 \pm 1.58$ & $1.86 \pm 0.53^{a}$ & $1.02 \pm 0.31^{\mathrm{a}}$ & $2.54 \pm 0.90^{\mathrm{a}}$ \\
\hline & $\mathrm{T} 2$ & $0.00 \pm 0.00$ & $0.00 \pm 0.00^{b}$ & $0.00 \pm 0.00^{\mathrm{b}}$ & $0.00 \pm 0.00^{b}$ \\
\hline
\end{tabular}


Okafor ./ Nig. J. Biotech. Vol. 37 Num. 1: 109-121 (June 2020)

\begin{tabular}{|c|c|c|c|c|c|}
\hline Securidaca & $\begin{array}{l}\text { T1 } \\
\text { T2 }\end{array}$ & $\begin{array}{l}0.00 \pm 0.00 \\
0.00 \pm 0.00\end{array}$ & $\begin{array}{l}0.00 \pm 0.00 \\
0.00 \pm 0.00\end{array}$ & $\begin{array}{l}0.00 \pm 0.00 \\
0.00 \pm 0.00\end{array}$ & $\begin{array}{l}0.00 \pm 0.00 \\
0.00 \pm 0.00\end{array}$ \\
\hline \multicolumn{6}{|l|}{ After 49 Days } \\
\hline & & $\mathbf{N L}$ & LL (cm) & LD (cm) & LA $\left(\mathrm{cm}^{2}\right)$ \\
\hline Ocimum & $\begin{array}{l}\text { T1 } \\
\text { T2 }\end{array}$ & $\begin{array}{l}13.08 \pm 4.47 \\
13.00 \pm 5.58\end{array}$ & $\begin{array}{l}3.51 \pm 0.81 \\
2.62 \pm 1.09\end{array}$ & $\begin{array}{l}2.10 \pm 0.47 \\
1.64 \pm 0.68\end{array}$ & $\begin{array}{l}8.86 \pm 2.34 \\
5.46 \pm 2.41\end{array}$ \\
\hline Pterocarpus & $\begin{array}{l}\text { T1 } \\
\text { T2 }\end{array}$ & $\begin{array}{l}9.40 \pm 3.05^{\mathrm{a}} \\
0.00 \pm 0.00^{\mathrm{b}}\end{array}$ & $\begin{array}{l}1.99 \pm 0.82^{a} \\
0.00 \pm 0.00^{b}\end{array}$ & $\begin{array}{l}1.03 \pm 0.46^{a} \\
0.00 \pm 0.00^{b}\end{array}$ & $\begin{array}{l}4.05 \pm 2.71^{a} \\
0.00 \pm 0.00^{b}\end{array}$ \\
\hline Securidaca & $\begin{array}{l}\text { T1 } \\
\text { T2 }\end{array}$ & $\begin{array}{l}0.00 \pm 0.00 \\
0.00 \pm 0.00\end{array}$ & $\begin{array}{l}0.00 \pm 0.00 \\
0.00 \pm 0.00\end{array}$ & $\begin{array}{l}0.00 \pm 0.00 \\
0.00 \pm 0.00\end{array}$ & $\begin{array}{l}0.00 \pm 0.00 \\
0.00 \pm 0.00\end{array}$ \\
\hline
\end{tabular}

$\mathrm{NL}=$ Number of leaves, $\mathrm{LL}=$ Leaf length, $\mathrm{LD}=$ Leaf diameter, $\mathrm{LA}=$ Leaf area, $\mathrm{T} 1=$ Treated with $5 \mathrm{~g} / \mathrm{l}$ of IBA, $\mathrm{T} 2=$ Control

The stem-cuttings of $O$. gratissimum and $P$. mildbraedii cut at $15-20 \mathrm{~cm}$ showed better growth rate compared to the ones cut at $10-15$ $\mathrm{cm}$. This is in agreement with the study carried out by Okafor et al. (2015) on P. mildbraedii where cuttings of $15-20 \mathrm{~cm}$ length sprouted earliest and had vigorous growth than cuttings of 5 and $10 \mathrm{~cm}$ length. The better growth result obtained in stem cuttings lengths of $15-20 \mathrm{~cm}$ in the studied plants can be related to different factors such as level of endogenous auxins and other growth regulators which may be lower in small- sized cuttings thereby resulting to reduced growth percentage, the presence of more nodes on the stem cuttings with longer lengths resulted to more bud sprout and leaf formation (Hamilton et al, 2009). This however, implies that the length of the stem-cuttings contributes to the vegetative growth of the plant.

In determination of the number of roots per stem cutting (Table 3 ), the treated 0 . gratissimum had the highest number of roots followed by the control. The treated $P$. mildbraedii stem cuttings produced roots as well. This agrees with the previous reports of Tchoundjeu et al., 2002; Teklehaimanot et al., 2004; Sanoussi et al., 2012 who revealed that treating stem-cuttings by dipping in auxin solutions ranging from concentrations of 2.5 to $5 \mathrm{~g} / \mathrm{l}$ or when sprinkled with rooting powder stimulate the rhizogenesis of Prunus africana, Osyris Lanceolatata and Vitex donania stem cuttings, respectively . This, however, showed that treating stem cuttings with a rooting hormone such as IBA is more adequate for obtaining best responses by the stem cuttings in terms of root production. The inability of $P$. mildbraedii (control) to produce roots can be attributed to season among other factors in line with the work of Ngwuli et al. (2019) which revealed that $P$. mildbraedii proved difficult to root during the rainy season in Nigeria. Despite the treatment, none of the stem cuttings of $S$. longepedunculata produced roots.

Table 3: Mean number of roots produced by the stem cuttings of $O$. gratissimum, $P$. mildbraedii and $S$. longepedunculata 
Okafor ./ Nig. J. Biotech. Vol. 37 Num. 1: 109-121 (June 2020)

\section{O. gratissimum}

P. mildbraedii

S. longepedunculata

\begin{tabular}{|l|l|l|l|}
\hline T1 & $135.00 \pm 13.45^{\mathrm{a}}$ & $1.33 \pm 0.01^{\mathrm{a}}$ & $0.00 \pm 0.00$ \\
\hline T2 & $61.66 \pm 2.34^{\mathrm{b}}$ & $0.00 \pm 0.00^{\mathrm{b}}$ & $0.00 \pm 0.00$ \\
\hline
\end{tabular}

T1 = Treated with $5 \mathrm{~g} / \mathrm{L}$ of IBA, T2 = Control.

It was also observed that $S$. longepedunculata stem-cuttings did not show any sign of growth in all parameters studied after the experimental period. This can be traced to the fact that it is a woody plant and the recalcitrant nature of most woody plants make regeneration difficult. This

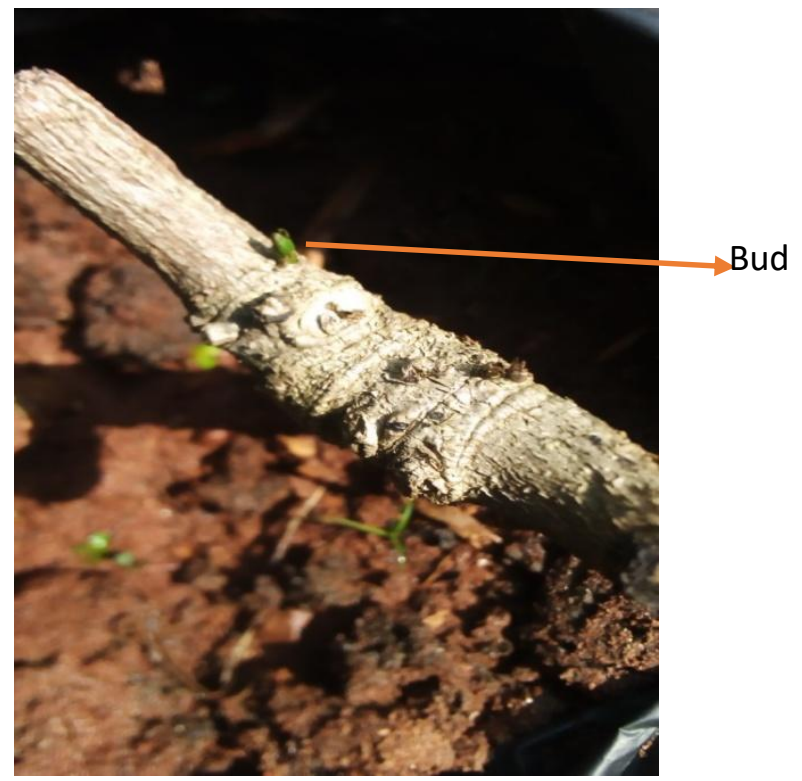

Plate 1: Bud sprout on P. mildbraedii stemcutting conformed to earlier report of Solomon and Belayneh (2017) on the investigation on Acacia lahai which showed that regeneration of woody plants has been a challenge due to their slow growth and unresponsive characteristics of the plant cell to plant growth regulators.

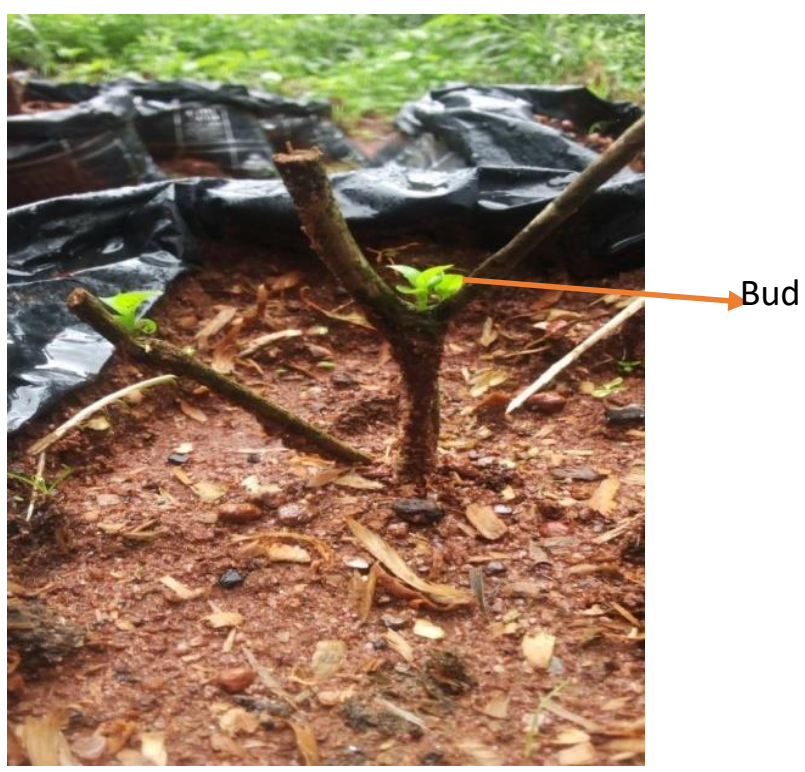

Plate 2: Bud sprout on O. gratissimum stem-cutting 
Okafor ./ Nig. J. Biotech. Vol. 37 Num. 1: 109-121 (June 2020)

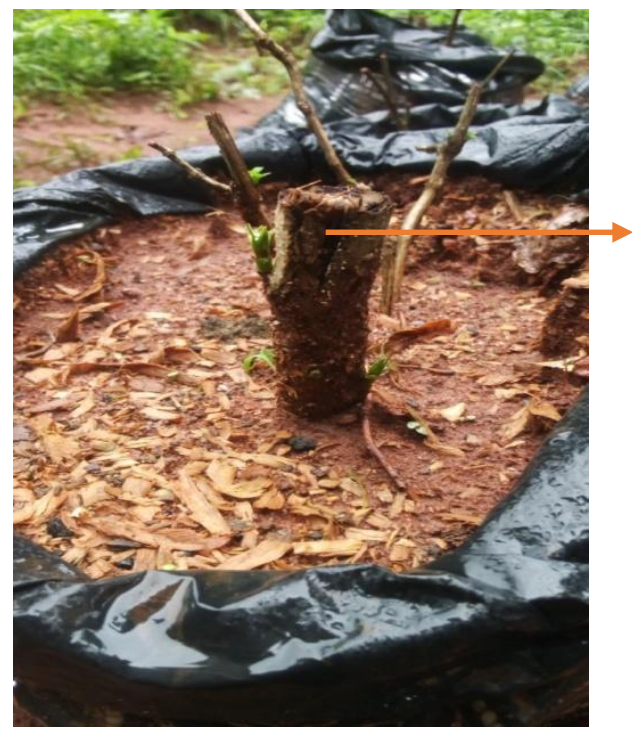

Plate 3: Multiple bud sprout by $P$. mildbraedii stem cutting.

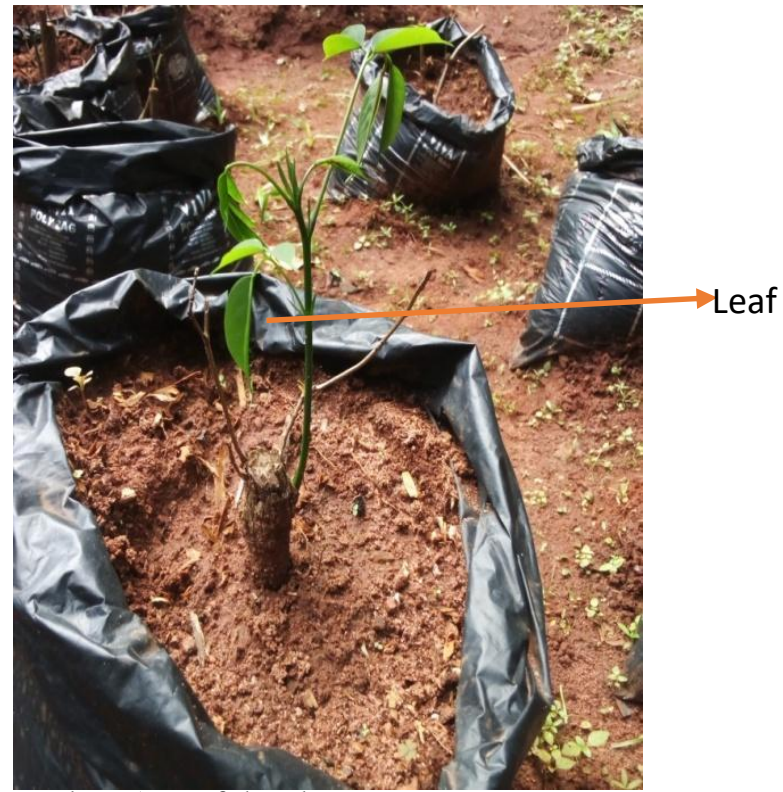

Plate 5: Leaf development on stem cutting of $P$. mildbraedii
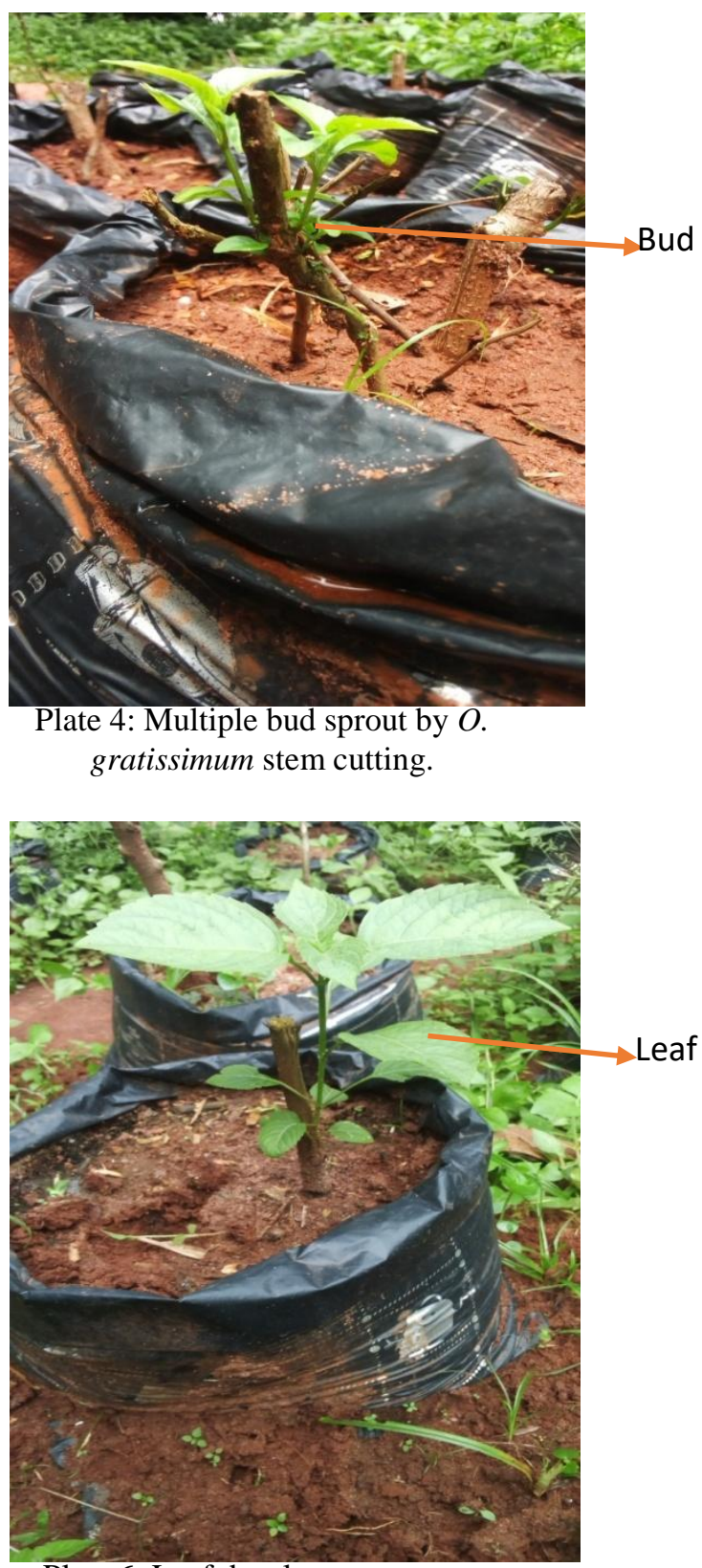

Plate 6: Leaf development on stem cutting of $O$. gratissimum 
Okafor ./ Nig. J. Biotech. Vol. 37 Num. 1: 109-121 (June 2020)

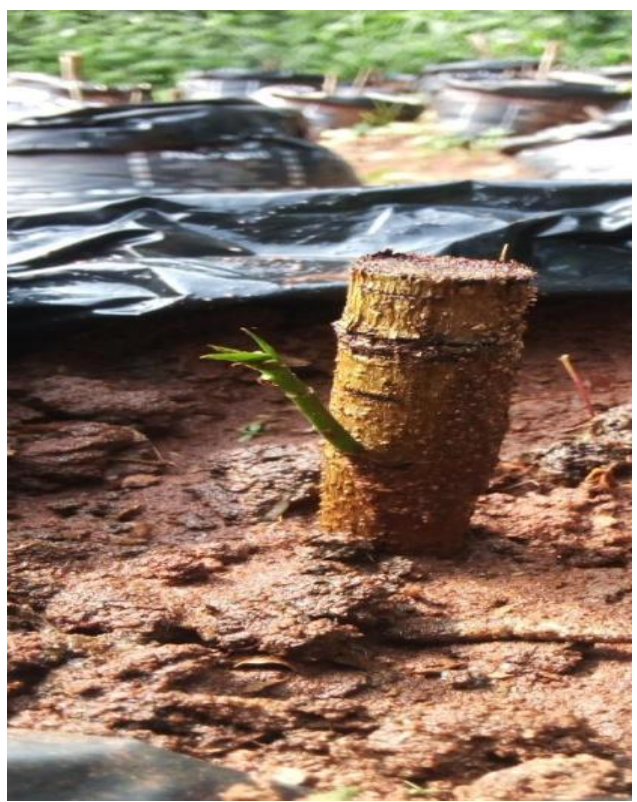

Plate 7: Stem cutting of $P$. mildbraedii at $15-20 \mathrm{~cm}$ length after 28 days of planting.

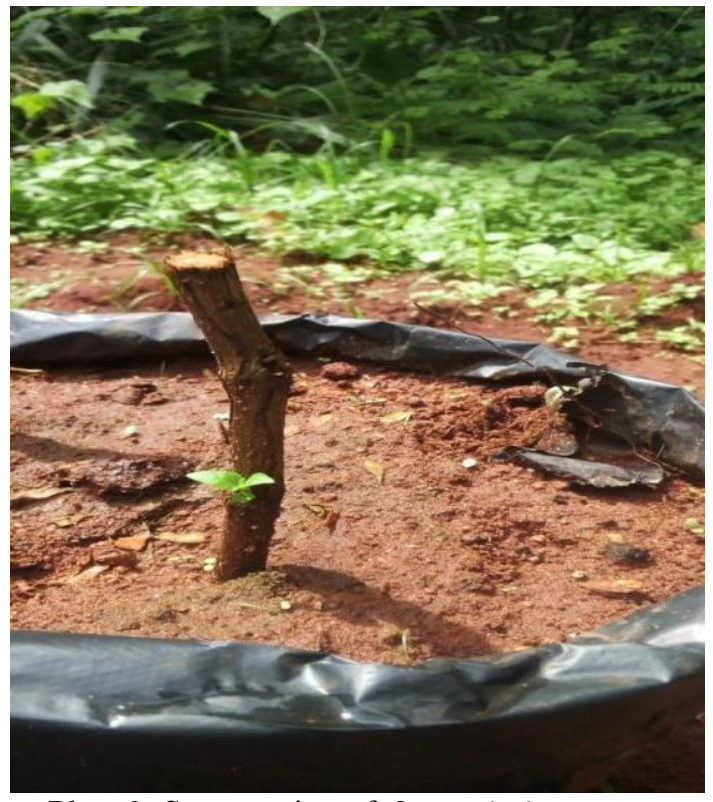

Plate 9: Stem cutting of $O$. gratissimum at $10-15 \mathrm{~cm}$ length after 21 days of planting

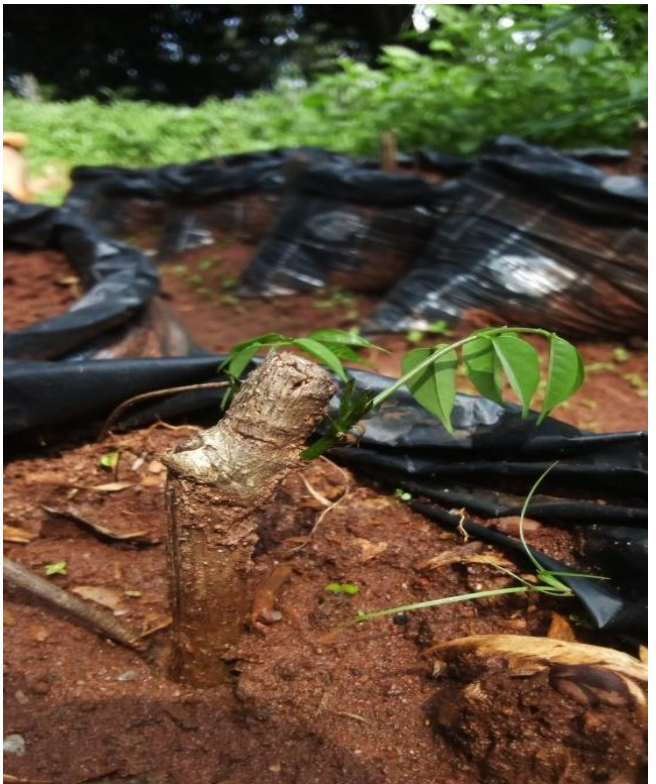

Plate 8: Stem cutting of $P$. mildbraedii at $10-15 \mathrm{~cm}$ length after 28 days of planting.

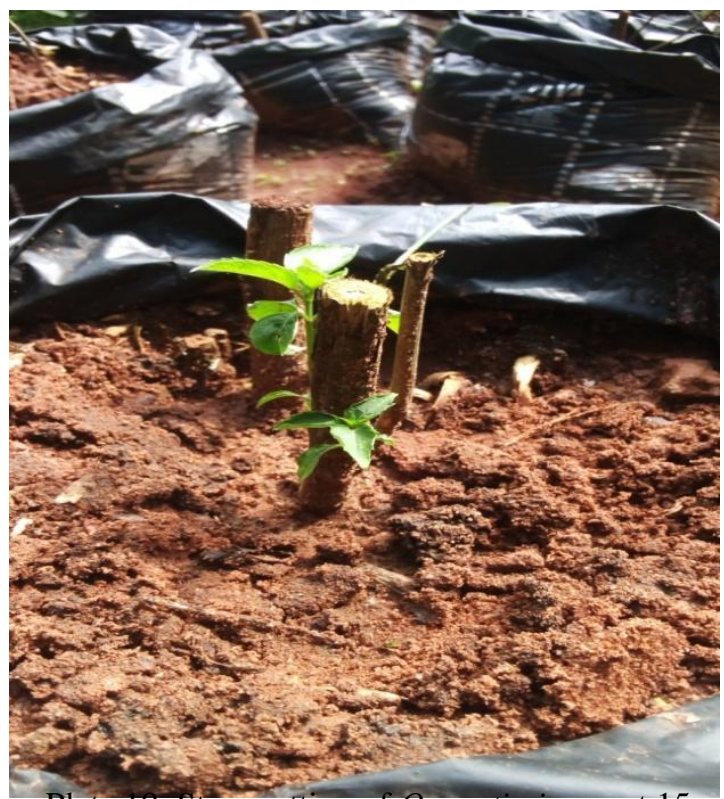

Plate 10: Stem cutting of $O$. gratissimum at $15-$ $20 \mathrm{~cm}$ length after 21 days of planting 


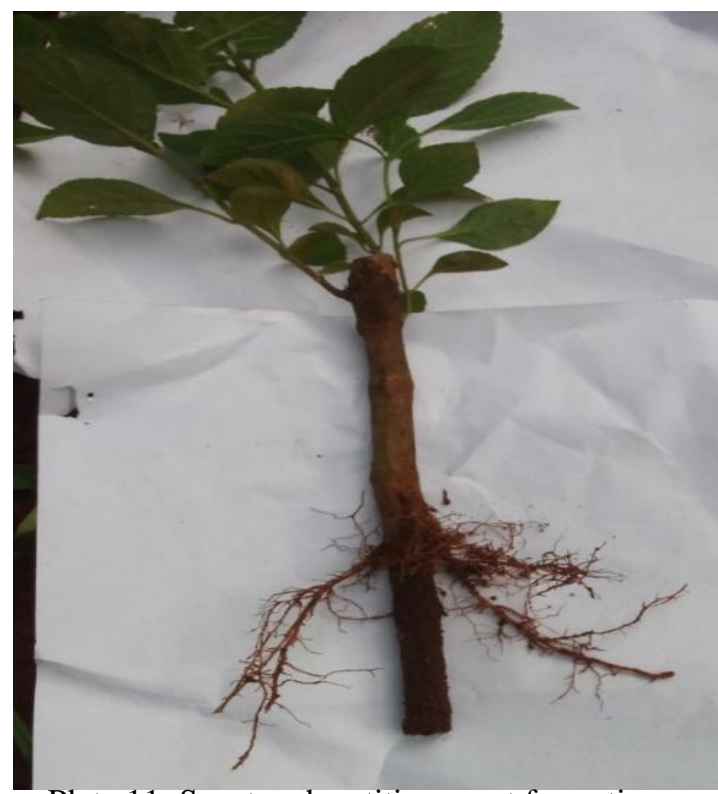

Plate 11: Scanty adventitious root formation on $O$. gratissimum stem-cutting that served as control.

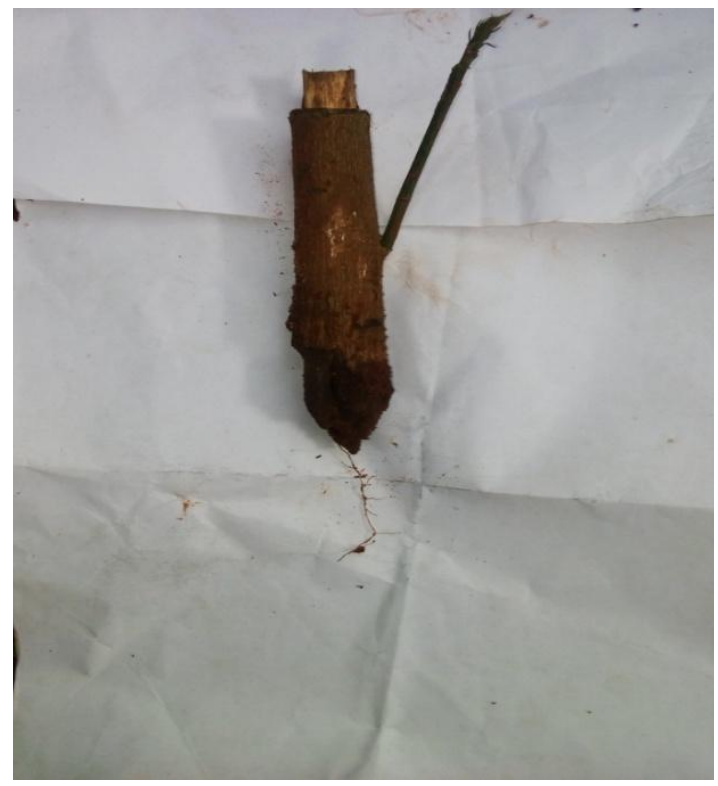

Plate 13: Root formation on P. mildbraedii stem cutting treated with $5 \mathrm{~g} / \mathrm{l}$ of IBA

\section{Conclusion}

The plant $P$. mildbraedii has been proven difficult to cultivate/regenerate during the rainy season. This study has revealed that regeneration can be achieved by treating the stem cuttings with the appropriate concentrations of Indole-3-Butyric

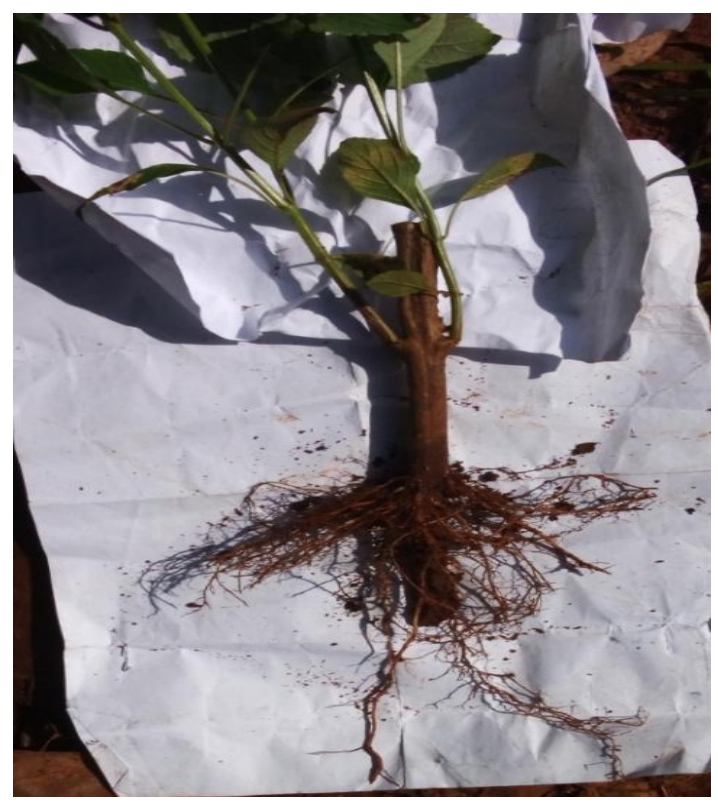

Plate 12: Numerous adventitious root formation on $O$. gratissimum stem cutting that was treated with $5 \mathrm{~g} / \mathrm{l}$ of IBA.

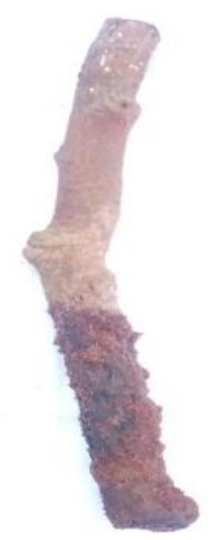

Plate 14: P. mildbraedii stem-cutting that served as control showed no root formation

Acid (IBA). The high percentage of rooting responses of the treated $O$. gratissimum stemcuttings can be relied upon for mass production of the species for future biotechnological exploitation of the species' bio-active compounds. For effective and efficient regeneration and domestication of $P$. mildbraedii 
and 0. gratissimum, stem-cutting lengths of 15 $20 \mathrm{~cm}$ which showed better growth compared to the cuttings of $10-15 \mathrm{~cm}$ should be utilized. However, further studies are necessary for developing a regeneration method for $S$. longepedunculata using the stem cuttings.

\section{References}

Afolayan, A. J. and Adebola. P. O. (2004). In vitro propagation: A biotechnologial tool capable of solving the problem of medicinal plants decimation in South Africa. African J. of Biotech, 3:683-687.

Aguiyi, J. C., Obi, C. I., Gyang, S. S. and Igweh, A. C. (2000). Hypoglycaemic activity of Ocimum gratissimum in rats. Fitoterapia .71 (4): 444-60.

Alafe, A. O., Elufioye, T. O., Faborode, O. S. and Moody, J.O. (2014). Anti-Inflamatory and Analgesic Activities of Securidaca longepedunculata (Polygalaceae) Leaf and Stem Bark Methanolic Extract. African J. of Biomedical Res, 17(3):187-191.

Alagesaboopathi, C. (2012). Effect of IAA and IBA on the rooting of Andrographis macrobotrys stem cuttings, an endangered medicinal plant of India. Intern/ J. of Recent Sci Res., 3 (2): 68 - 70.

Alice, T., Disha, N. and Mukesh, S. (2014). Collection and conservation of endangered medicinal plant species diversity for maintaining ecological balance. Recent Res in Sci and Tech. 6(1): 167-170.

Birnbaum, K. D. and Sánchez-Alvarado, A. (2008). Slicing across kingdoms: regeneration in plants and animals. Cell, 132: 697-710.

Chupeau, M.C., Granier, F., Pichon, O., Renou, J.P., Gaudin, V. and Chupeau, Y. (2013). Characterization of the early events leading to totipotency in an Arabidopsis protoplast liquid culture by temporal transcript profiling. Plant Cell. 25: 2444-2463.

Dawit, A., Asfew, D. and Kelbesa, U. (2003). Medicinal plants and other useful plants of Ethiopia: Ethiopian Health and Nutrition Research Institute (EHNRI). Cameras Pix Publishers International: Nairobi Kenya. pp 100.
Donald, Z., Blackson, L. K., Thokozani, K., Gudeta, W. S., Zewge, T., Dominic S. B., Viswanbharen, S. and Philip, C. S. (2011). Propagation of the African medicinal and pesticidal plant, Securidaca longepedunculata. African J of Biotech, 10(32): 5988-5992.

Elhaak, M. A., Matter, M. Z., Zayed, M. A. and Gad, D. A. (2015). Propagation Principles in using Indole-3-Butyric Acid for Rooting Rosemary Stem Cuttings. Jo of Horticult, 2(1):121.

Elizabeth, O. A., Henrietta, O. O., and Lyle, E. C. (2012). Growth and Essential Oil Yield of African Basil, Ocimum gratissimum under Light and Water Stress. Jo of Medicinally Active Plts. 1(4): 3-9.

Fadli, A., Attaaoui, A., Chetto, O., Boudoudou, D., Talha, B.A., Benkirane, R. and Benyahia, H. (2017). Propagation of citrus rootstocks by stem cutting using auxin pretreatments: the case of Citrus melo (Citrus paradisi Macf. $\mathrm{X}$ Poncirus trifoliata). Jo of Mat and Environ Sci, 8(11): 40854093.

Faridah, Q.Z., Abdelmageed, A.H.A., Julia, A.A., Hafizah, R. (2011) Efficient in vitro regeneration of Zingiber zerumbet Smith (a valuable medicinal plant) plantlets from rhizome bud explants. African J. of Biotech, 10(46):9303-9308.

Hamilton, C. J., Emino, E. R., Bartuska, A. C. (2002). The influence of cutting size, leaf area and shipping on Coleous cutting quality parameters including rooting. Proceedings Florida State Horticultural Society, 115: 134-136.

Hunt, M.A., Trueman, S.J. \& Rasmussen, A. (2011). Indole-3-Butyric Acid accelerates adventitious root formation and impedes shoot growth of Pinus elliottii var. elliottii $\times$ P. caribaea var. hondurensis cuttings. New Forests, 41(3): 349-360.

Ikeuchi, M., Ogawa, Y., Iwase, A. And Sugimoto, K. (2016). Plant regeneration: Cellular origins and molecular mechanisms. Development, 143: 14421451.

Kouakou, K.L., Dao, J.P., Kouassi, K.I., Beugre, M.M., Kone, M., Baudoin, J.P., Zoro, I.A. (2016). 
Propagation of Garcinia kola (Heckel) by stem and root cuttings. Silva Fennica, 50: 4-17.

Kuldeep, Y., Narender, S. and Sharuti, V. (2012) Plant tissue culture: a biotechnological tool for solving the problem of propagation of multipurpose endangered medicinal plants in Indian J of Agricult. Tech. 8(1): 305-318.

Ludwig, M. J. (2000). Indole-3-Butyric Acid in plant growth and development. Plant Grow. Regulat, 32: 605-620.

Mahipal, S. and Manokari, M. (2016). Impact of Auxins on Vegetative Propagation through Stem Cuttings of Couroupita guianensis Aubl: A Conservative Approach. Scientifica, 206:56-63.

Melnyk, C. W. and Meyerowitz, E. M. (2015). Plant grafting. Afri J. of Hort. 25: 183-188.

Mohammed, A., Tanko, Y., Okasha, M. A., Magaji, R. A. and Yaro, A. H. (2007). Effects of aqueous extract of Ocimum gratissimum on blood glucose levels of Streptozotocin-induced diabetic wistar rats. Afri. J. of Biotech, 6(18): 2087-2090.

Ngwuli, C. P., Mbakwe, R. and Uwaga, A. M. (2019). Effect of different soil types and season on the vegetative propagation of Pterocarpus species in the humid tropic of south eastern Nigeria. J. of Res in Forest, Wildlife \& Environ, 11(1): 107-118.

Nweze, E.I., Okafor, J.I., Njoku, O. (2004). Antimicrobial activities of methanolic extracts of Trema guineensis (Schumm and Thorn) and Morinda Lucida Benth used in Nigeria herbal medicinal practice. Jo of Bio Res and Biotech, 2(1):36-39.

Nzekwe, U. (2002). Studies on some aspects of the Biology and ecology of Irvingia wombolu syn. I. gabonensis var. Ecelsa Ph.D Thesis, (Unpublished) Department of Botany, University of Nigeria, Nsukka: Nsukka, Enugu. 155 pp.

Ojewole, J. A. O. (2008). Analgesic, antiinflammatory and hypoglycaemic effects of Securidaca longepedunculata (Polygalaceae) root bark aqueous extract. Inflammopharmacology, $1: 174-181$.
Onyeulo, Q. N., Okafor, C. U. Okezie, C. E. A. (2018) Antioxidant capabilites of three varieties of Elaeis guineensis Jacq. on the basal media of Murashige and Skoog, Gamborg and Eeuwens. Pak. J. Bot. 50(4): 1467-1476,

Owulade, M. O. (2004). Handbook African Medicinal Plants. CRC Press, Boca Raton, Florida. pp 23.

Pulianmackal, A. J., Kareem, A. V. K., Durgaprasad, K., Trivedi, Z. B. and Prasad, K. (2014). Competence and regulatory interactions during regeneration in plants. Front Plant Sci., 5: 142.

Rosemary, I.U., Gabriel, U. I., Uche, E. E., Chioma, O. I. and Kenneth, O. A. (2015). Identification of Phytochemicals Present in the Leaves of Pterocarpus Mildbraedii Harms by GC/MS Analysis. J. of Appl Chemi, 8(7): 6-10.

Sani, M. B., Nzekwe, U. And Okirikata, E. (2016). Studies on Auxins in the rooting of Moringa oleifera Stem Cuttings. Lambert Academic Publishers: USA. 55 pp.

Sanoussi, A., Ahoton, L.E., Odjo, T. (2012). Propagation of Black Plum (Vitexdonania Sweet) using stem and root cuttings in the ecological conditions of South Benin. Tropicultura, 30: 107112.

Simon,A. and James,E. (2007). Basil new crop sheet. Afri J. of Biotech, 6 2087-2090.

Slater, A., Scott, N., and Fowler, M. (2003). Plant regeneration through tissue culture. Plant Biotechnology, Oxford Press: London. pp 334.

Soumen,S., Abdul,K., Chandan,S. and Parthadeb,G. (2012). In Vitro Propagation of Ocimum gratissimum L. (Lamiaceae) and Its Evaluation of Genetic Fidelity Using RAPD Marker. Ame J. of Plant Sci, 3: 64-74.

Tandon, P., Kumaria, S. and Nongrum, L. (2009). Conservation and management of Plant genetic resources of Northeast India. Indian $J$ of Trad. Know, 8(1): 29-34.

Tchoundjeu, Z., Avana, M.L., Leakey, R.R.B., Simons, A.J., Asaah, E., Duguma, B. (2002). 
Vegetative Propagation of Prunus Africana: effects of rooting medium, auxin concentration and leaf area. Agroforestry Systems, 54(3); 183192.

Teklehaimanot, Z., Mwangingo, P.L., Mugasha, A.G., Ruffo, C.K. (2004). Influence of the origin of stemcutting, season of collection and auxin application on the vegetative propagation of African Sandalwood (Osyris Lanceolatata) in Tanzania. South African Fores. Jour, 20(1):13-24.

Thangavel, K., Ebbie, M.B. and Ravichadran, P (2014). Biotechnology and I n Vitro Conservation of Medicinal Plants. Annals of Plant Sci, 3(06): 734-744.

Tognetti, W.B., Aken, O.V., Morreel, K., Vandenbroucke, K., Van, B., Clercq, I., Chiwocha, S., Fenske, R., Prinsen, E., Boerjan, W., Genty, B., Stubbs, K.A., Inze, D and Van, B. F. (2010). Perturbation of Indole-3- Butyric Acid homeostasis by the UDP-Glucosyltransferase UGT74E2 modulates, Arabidopsis architecture and water stress tolerance. Plant Cell, 22: 26602679.

Tripathi, M. (2008). Tissue culture technology and transgenic biology - A boon or bane? Current Science, 94: 7-8.

Zhang, T. Q., Lian, H., Tang, H., Dolezal, K., Zhou, C. M., Yu, S., Chen, J. H., Chen, Q., Liu, H., Ljung, K. (2015). An intrinsic micro RNA timer regulates progressive decline in shoot regenerative capacity in plants. Plant Cell, 27: 349-360. 